\title{
A suggested three-fold matrix of cost rationalization and performance enhancement
}

Esraa khairy abu dahab hussien Prof. Mohamed Mostafa El Gebaly

Demonstrator of Accounting at

Faculty of Business Administration-

Nahda University
Professor of Cost Accounting

at Faculty of commerce-

Beni-Suef University

\section{Abstract: -}

This research presents the reciprocal and interactive relationships between three important approaches to cost rationalization have been addressed, namely: the quality function deployment, value engineering, and the target costing approach, and the research mainly aims at the integration between the quality function deployment and value engineering and the target costing approach that helps in rationalizing the cost of products without compromising their quality by achieving the desires and requirements of customers at the lowest possible cost enables competition in the market, and helps companies to survive, grow and continue, by focusing on customer priorities and accessing alternatives to product components with the characteristics and features required by customers that can be produced at a lower cost which contributes to cost rationalization.

Key words: Quality function deployment (QFD), Target costing (TC), Value engineering (VE), Cost rationalization, Customer satisfaction.

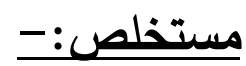

هذا البحث يعرض العلاقات التبادلية والتفاعلية بين ثلاثة مناهج لترشيد التكلفة وهما: مدخل

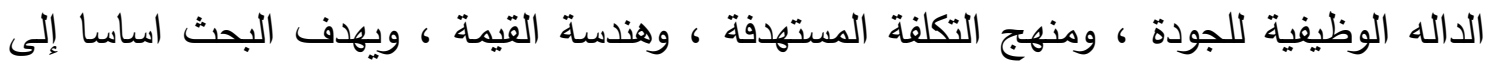

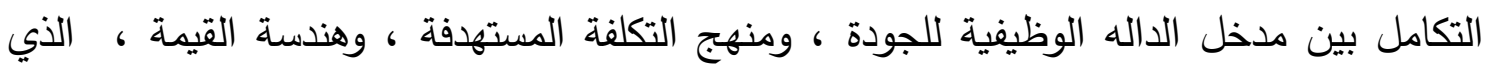

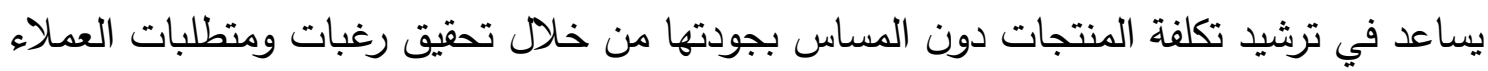

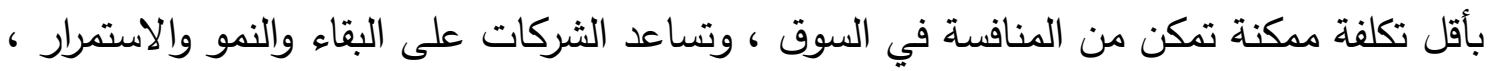




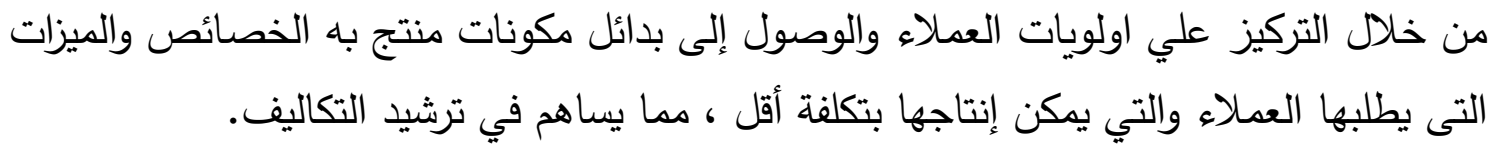

\section{Introduction:}

As a result of the diversity of customers' needs for products and services, facilities went to search for strategies that help in achieving customer satisfaction and providing their needs with the aim of maintaining them, and access to products at the lowest possible cost while maintaining the appropriate quality level, and rationalization of cost is one of the old strategies pursued by facilities to achieve customer satisfaction, Rationalization of the cost is closely related to the quality of the product, as rationalization alone without maintaining quality may not meet the required result of customer satisfaction, and this is why many enterprises have sought to find ways to rationalize the cost while taking into consideration the quality of the product in order to obtain a competitive advantage, so many techniques and approaches have emerged to rationalize the cost while maintaining quality (Al-olimat,2020).

Based on the aforementioned, this chapter is mainly concerned with how to design a three-dimensional matrix for strategy to rationalize cost and maximize performance, through integration between the three approaches that include the quality function deployment and target costing and value engineering, and by taking advantage of the advantages of this integration. finally, we can reach the desired goal, which is real and continuous cost rationalization.

\section{Research Problem: -}

The problem of research is how to design and produce products that have the characteristics and features required by the customers and at the lowest possible cost to enable enterprises to compete and stay in the market and the search for an approach that leads to providing a highquality product that meets the requirements and specifications of customers at the lowest possible cost, through the application of the three of the most important cost management approaches to rationalizing the costs of the products without compromising their quality. It was thought that the combination of three important cost management approaches such 
as Quality Function Deployment (QFD), Target Costing (TC) and Value Engineering (VE) will help solve the research problem.

\section{Research objective: -}

The research aims to integration between three of the most important cost management and rationalization approaches, namely Quality Function Deployment (QFD), Target Costing (TC) and Value Engineering (VE) to reach the rationalization of the cost of products without compromising their quality, maximizing profitability and improving quality, by achieving the desires, needs and expectations of customers at the lowest possible cost, it enables companies to compete in the local, regional and global market, and helps companies to survive, grow and continue, by highlighting customers' priorities for the needs they need and identifying alternatives to designs that can be produced at a lower cost. Enhancing the theoretical framework of the three curriculum and recognizing the importance and advantages of each of them, with an integration between them highlighting the advantages of each of them separately.

\section{Plausibility and importance of the research: -}

The current study represents one of the very few studies which prepared to discuss the problem of rationalizing the cost of products while maintaining the required level of quality that meets the needs of customers and fulfills their requirements and expectations in the products and with the components of a product that features a set of characteristics and features that customers require. The research derives its importance through the availability of an integrated applied framework in rationalizing the costs of products without compromising their quality by using the integration between the deployment of the quality function (QFD), target costing (TC) and value engineering (VE), as well as the reasons for applying these approaches such as facing the sharp competition between industrial establishments, and economic openness, therefore, approaches should be adopted in line with the modern business environment characterized by intense competition, by following modern approaches to calculating costs and thus avoiding traditional approaches. In writing works and applying upon an Egyptian case, this study is the first pioneered study to be done. 


\section{Research Hypotheses: -}

- Different hypothesis will be tested within the context of this work as: -

1. The use of the quality function deployment contributes to identifying the priorities, needs and requirements of customers and translating into technical attributes.

2. The integration between the quality function deployment (QFD), target costing (TC) and value engineering (VE) contributes to rationalizing the costs of the products without compromising their quality and in a way that meets customer needs and expectations.

\section{Research plan: -}

In light of the research problem and in order to achieve its aims, the research is divided into the following points:

1. Prior Studies

2. The role of value engineering in achieving the target costing.

3. The role of Quality function deployment (QFD) in achieving the target costing.

4. Integration between Quality function deployment (QFD), Target Costing (TC) and value Engineering (VE).

5. Summary, Results and Recommendations.

\section{Prior Studies: -}

The researcher reviewed several scientific references on quality function deployment (QFD), value engineering (VE), target costing (TC), and references that combined two or three methods in integrative relationships. The researcher studied previous studies as follows:

\section{(Karimi and Jafari, 2014)}

The objective of this study is to develop a cost management system using the target cost system (TC), (QFD) and (VE). This study is based on developing the theoretical principles of the three approaches as a prelude to developing a mathematical model for the integration between these three 
systems by introducing a new product. The importance of the study is to search for a mathematical model that represents a comprehensive and integrated approach to improving cost management with the manufacture of new products through the three most effective and reliable models: (QFD), (VE), (TC), all these models despite the existence of weaknesses in it, but that by integrating with each other can be maintained benefits and capabilities. The study reached the development of nonlinear mathematical programming model, which integrates the three approaches and achieves maximizing the profit of the establishment, minimizing its costs and meeting customer needs.

\section{(El- Dalahmeh, 2018)}

This study aims to determine the extent of applying the target cost approach and value engineering to reduce the cost in the Jordanian public shareholding companies for food industries. To achieve the objectives of the study, the researcher distributed a personal questionnaire to a random sample of 145 accountants in the Kingdom of Jordan. The study found that the components of applying the target cost approach are available, as well as companies have awareness of the principles and importance of applying the target cost approach to managing and reducing costs with the aim of improving profitability, and companies use value engineering to reach the target costs. The results also showed that there are some difficulties encountered in applying target costs and value engineering in the Jordanian shareholding companies for food industries. The study presented a set of recommendations on adopting the target cost approach and value engineering in Jordanian companies and spreading cultural awareness about the target cost philosophy and value engineering.

\section{(Mahajan, et al, 2019)}

This study aims to present the basic principles of value engineering and its various stages that can be applied in order to improve the value of the products, as the material specifications of the product under study are changed according to the value engineering methodology and thus the materials that lead to the reduction of the cost of the product are selected without this change affecting its value and design. In order to obtain the best alternative from the available alternatives, another tool called the decision matrix was used, through which the most appropriate results can 
be obtained, as well as the ease of application and through value engineering analysis, the cost of the product can be reduced.

As a result of the previous studies, we will notice that a large portion of these studies focus on taking each approach of the approaches to cost management and rationalization under study (QFD, VE and TC), and limited attempts have also been made by researchers on how to integrate two approaches or between the three approaches, and although previous studies adopted different trends, However, it focused in general on finding proposed solutions to the problems facing companies, especially the high costs, as the current study meets many previous studies on common goals, perhaps the most prominent of which is the application of modern management accounting techniques, either one or more of that in cost rationalization and strengthening the competitive position, as well as Supporting the theoretical side of the current study in terms of the theoretical framework of the target cost and value engineering and their role in cost rationalization .The current study deals with (QFD, TC, VE) in detail and in depth, as well as the complementarities between these techniques in a way that makes them effective techniques in rationalizing product costs while maintaining the required level of quality, maximizing profitability and improving quality, in addition to focusing on customer satisfaction and meeting their requirements as an entry point to achieve competitive advantage. The current study also focused on the application of (QFD) as a support tool for value engineering.

\section{The role of value engineering in achieving the target costing:}

Value engineering is one of the most important tools used in the product design stage, which helps the designer to access products with low cost, as it is often the first design cost of the product that is greater than its target cost, so it is necessary to review the first design of the product, through the adoption of value engineering, with the aim of achieving the target costing (El-Balkey, 2008; El-Kabbajy, 2014; Blocher, et al, 2016; Abdel-Mawjod, 2017; Mahajan, et al, 2019).

Value engineering is one of the main tools used by production designers in achieving the target cost of their products due to the vital role it plays, as it works to search for potential areas to rationalize cost during 
the product design and planning stage as a complement approach to the target costing approach (El-kababjy,2014; El- Dalahmeh ,2018; Ahmed, 2018).

Value engineering is considered one of the most important tools used to achieve the target cost by modifying the product design that leads to rationalization of costs without compromising quality (El- Dalahmeh, 2018; Vijayan, et al, 2019).

Most companies apply the target costing and value engineering approaches together in order to find ways to increase job performance and maximize product quality within the target cost limits (Cooper and Slagmulder, 1997). It should be noted that there is a close relationship between the target costing and value engineering, especially in the product survival area, in order to achieve a balance between the following elements (Sharma, et al., 2011; Mahajan, et al, 2019):

1- The price.

2- Job performance.

3- Quality.

Also referred to is the role of value engineering in reducing product costs by conducting regular evaluations processes of all aspects of the value chain, with the aim of reducing costs while working to meet customer requirements or meet their needs, by making product design improvements or changes in material specifications or adjustments in manufacturing methods, it lead to reduce the costs that can be achieved to become close to or equal to the target cost (Hussein, 2003; Sharma,2012).

On the other hand, looking at the role of value engineering in achieving the target costing by describing it with the technique that works to find creative ways to reach the target cost, according to value engineering, design engineers work to modify the design of some of the product components and simplify the process of manufacturing and maintenance and replace some materials with less expensive ones without reducing its value from the customer's point of view and improving the efficiency of production processes, that the important criterion that production engineers and product designers must adhere to is a correct and clear understanding of the value of the product from the customer's point 
of view, so according to this technique the engineering team works with suppliers to Providing some raw materials or components that meet the target cost, value engineering works to analyze and design the product, in order to delete the elements that do not add value to the product while maintaining customer satisfaction to achieve the target cost and promote activities that add value to the product (Langfield, et al, 2009; Blocher, et al, 2016).

Value engineering is used to achieve the target costing for the purpose of rationalizing the cost of the product, by analyzing the available alternatives to the characteristics (functions) and product costs to meet the desires of consumers, and working to exclude characteristics and then unnecessary costs from the new or existing product, and value engineering focuses on several methods, including functional analysis that is used to examine the performance and cost of each function or an essential part of the product, and then to achieve a balance between them, until the required level is achieved to achieve performance for each function while keeping all function costs at a level below the target cost (ELhag and Elyas, 2017) .

\section{The role of Quality function deployment (OFD) in achieving the target costing:}

The QFD tool helps identify candidate components for reduction and rationalization by linking customer requirements to product components (Amara, 1998) (Annappa and Panditrao, 2013). In working life, companies rarely reach the target cost from the first attempt, so attempts should be repeated again in order to achieve the target costing. Therefore, QFD, which is a technology for exchanging and classifying information, plays a major role in this repetitive process, and the most important advantage of this technology is its ability to Concentration of various information in a small space that is easily understood by making a matrix that includes customer requirements, the value that customers expect and what customers actually receive in addition to the internal characteristics of the product while measuring those characteristics and comparing the product with competitors' products, all of this enables designer to compare the product that they designed with the competitors 'product and compare the product's performance with the customers' expectations in addition to linking internal processes with job performance, that the comparison between cost and specifications can be made when the relationship between 
internal and external characteristics is clear, a specific feature may be change in a non-main aspect among the aspects of the product in order to reduce the cost, on the contrary, the specifications may be improved at a low cost if the economic unit wants to increase the prices of products (Khalil, 2012; Chin, et al,2019).

It was thought that the use of the QFD leads to rationalizing costs, improving the value of products and developing them and enhances their market share, as well as the ability to make decisions related to the production process, through the presence of matrices related to the quality house linked to and affecting the requirements of the customer and competitors in the market. As it turns out that the use of value engineering and QFD in an integrated manner is better if each technique is used separately.

Al-Tammy and Shihab add that the QFD tool is one of the important tools through which to reach the target cost in addition to value engineering, as it translates the customer requirements that are described as comprehensive, as it is used in the product design stage (Al-Tammy and Shihab, 2010).

As the value engineering techniques and QFD can be relied heavily at the product design stage, through QFD, it is possible to link between customer requirements and product components in order to reach the relative importance of these components, that is, the extent of its contribution to meeting customer requirements, as for value engineering, it works to reduce the costs of the product without compromising its quality through the value index of the candidates components for reduction and then achieve the target cost reduction (Amara, 1998). From another point of view, the value engineering and QFD techniques have them Different directions, as value engineering focuses mainly on reducing costs as well as supporting operational processes that lead to lower costs, in addition to that, value engineering chooses the alternatives that provide the product with the greatest possible value from the customer's point of view, while the QFD tool focuses on customer needs and their requirements (Yegengi, et al, 2011).

It was thought that there are some common characteristics between the target costing, value engineering, and QFD, for example: 
1- Applying both target cost, QFD and value engineering at the design stage.

2- Work to meet the requirements of customers.

3- Team work.

It was thought that the integration between the quality function deployment (QFD), value engineering (VE), and target costing (TC) contributes to reaching products that satisfy and meet the needs of customers, with technical components that have the characteristics and features that customers need and expect, and at a lower cost. This, in turn, leads to rationalizing the costs of the products without compromising their quality.

The previous discussions about target costing, QFD, and value engineering indicate their complementary aspects. The primary objective of target costing is rationalizing costs to the level that both satisfies customer requirements and meets the firm's target profits. Value engineering has the primary objective of maximizing customer value; its efforts to increase functionality and quality while at the same time rationalizing cost. QFD identifies critical customer preferences that define product's desired functionality, and provides a structured approach to ensure customer desires are not compromised during design process. Figure 1 shows how the information provided by QFD and value engineering supports target costing approach.

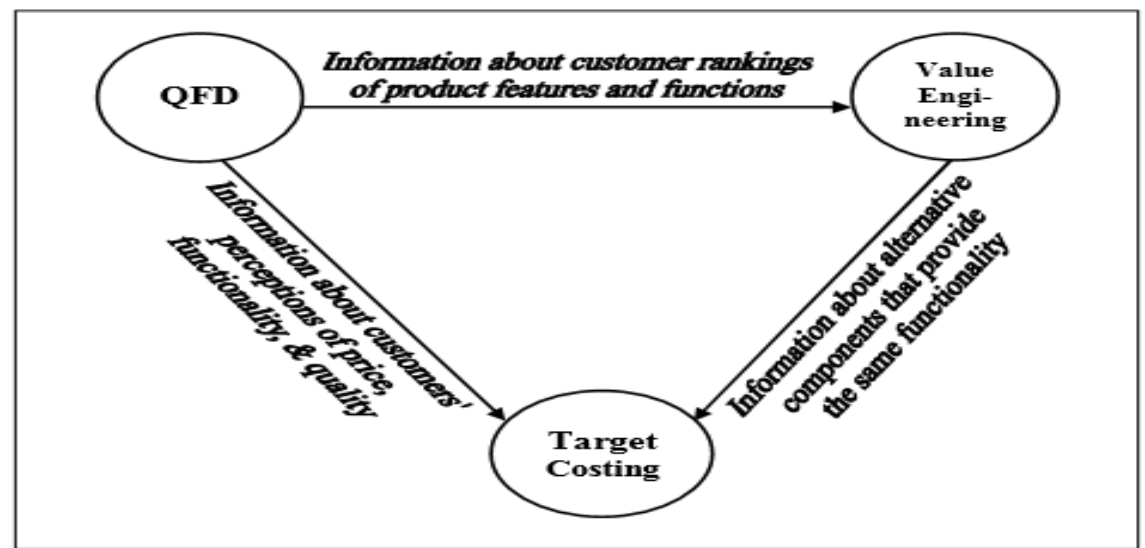

Figure 1 (Achieve the target costing using value engineering and the quality function deployment)

Source: (AL-Qady, 2013) 
From the previous figure 1, it can be noted that:

QFD provides information about customers' perceptions with respect to desired prices, features, and quality. this information is serious in the first step of target costing which is concerned with strategically determining the target selling price.

QFD benefits designers break down the total product target cost into the components that make up the product.

QFD provides information about customer classifications of value to customers about product's features and functions. this information supports value engineering to focus improvement efforts on the functions that are most attributable to customer.

Value engineering provides target costing with information about alternative materials, parts, and components that offer the same functionality to customers while maintaining the total target cost.

\section{Integration between Quality function deployment (QFD), Target Costing (TC) and value Engineering (VE):}

The target costing approach is of particular importance in light of the severe competition conditions, in order to survive, grow and continue, and the establishment has two options to rationalize costs and make them reach the target cost level:

The first option: integrating new manufacturing technologies and using advanced cost management techniques such as activity-based costing system, and strive to increase productivity

The second option: redesigning products or services.

Many companies use both options: efforts to achieve an increase in productivity and to identify lower-cost designs, which leads to reaching the targeted costs. And this approach is considered a useful method, through which can differentiate between performing a job and the cost of this job. And (Blocher, et al, 2010) believes that accomplishing the target costing approach requires several steps, which are:

1- Determine the target market price.

2- Determine the desired profit margin. 
3- Calculate the permitted target cost.

4- Use value engineering technology to determine ways to reduce costs.

5- Use the Kaizen Costing System and Operational Control to create an additional cost reduction for the products.

It was thought that the introduction of the quality function deployment to these steps will help in identifying the priorities of customer needs, and arranging these priorities to identify the appropriate place to reduce and rationalize the cost. This is what some emphasized that the use of the quality function deployment means that the quality criterion prevails when studying the relationship between costs and product characteristics, through the integration of value engineering with the target costing approach, and market analysis after determining which parts of the product can be applied to the target costs with a higher priority, and thus redesigned for the purposes of creating a greater cost reduction (El Helbawi and El Nashar, 2013). Therefore, the target costing approach in its integration with the quality function deployment and value engineering will achieve many advantages, including:

1- Increasing customer satisfaction by focusing on designs that add value to them, by applying the quality function deployment.

2- Reducing costs by increasing the efficiency and effectiveness of designs, by making use of value engineering technique by searching for a quality of raw materials that are used to accomplish several characteristics at the same time.

3- Helping enterprises towards achieving the desired profit on their new products, as well as their existing products that are being redesigned.

4- Reducing the total time needed to develop products, by improving coordination between the stages of design, manufacture and marketing, by applying the Kaizen method for continuous improvement to complete cost reduction programs.

5- Helping establishments towards finding a competitive advantage in times of the Economic Recession. 
6- Improving the overall quality of products, by taking care of the design stage and taking into consideration manufacturing issues when developing possible designs.

\subsection{Complementarities between the three approaches:}

The notes are (Cooper and Slagmulder , 1997) and (Monden ,1992) from and current industry practices also indicate that the target cost approach has paved the way to set cost targets, relying on tools and approaches such as: Quality Function deployment, Value Engineering and Design for Manufacturing (DFM) to achieve the required cost (Gandhinathan,etal,2004).

The application of a tool of cost management tools such as the target costs leads to reaching a model for product design that is characterized by high capabilities, and the quality function deployment determines the needs of customers and links them with engineering requirements, in order to reach a design based on customer needs, and reduces the speed of changing those needs, and on the other hand, value engineering technique leads to the optimal allocation of resources, according to the level of importance of product functions, as the quality function deployment emphasizes that the right product is the one that should be designed, while value engineering technique emphasizes that designing the right product should be in the best possible way (Karimi and Jafari, 2014).

So, a target cost approach can integrate with value engineering and QFD at the product design stage in order to rationalize costs and develop Products (Prasad et al, 2011; Sharma, 2012). value engineering and QFD are engineering techniques that help design engineers reduce and rationalize product costs so that value engineering focuses on maximizing customer value, while QFD focuses on spreading customer requirements when designing a product (Cooper and Slagmulder, 2004; Ahmad, 2018).

Cooper and Slagmulder discussed in their books in 1997 the interaction between the target costing approach and value engineering, and concluded that the survival of any product requires that it has three characteristics: price, functionality, and quality, and they reached how these three factors can interact with each other to provide a work area that helps the establishment to keep its products in the competition market. They provided the following figure: 
Figure 2 to show the interaction between the three factors:

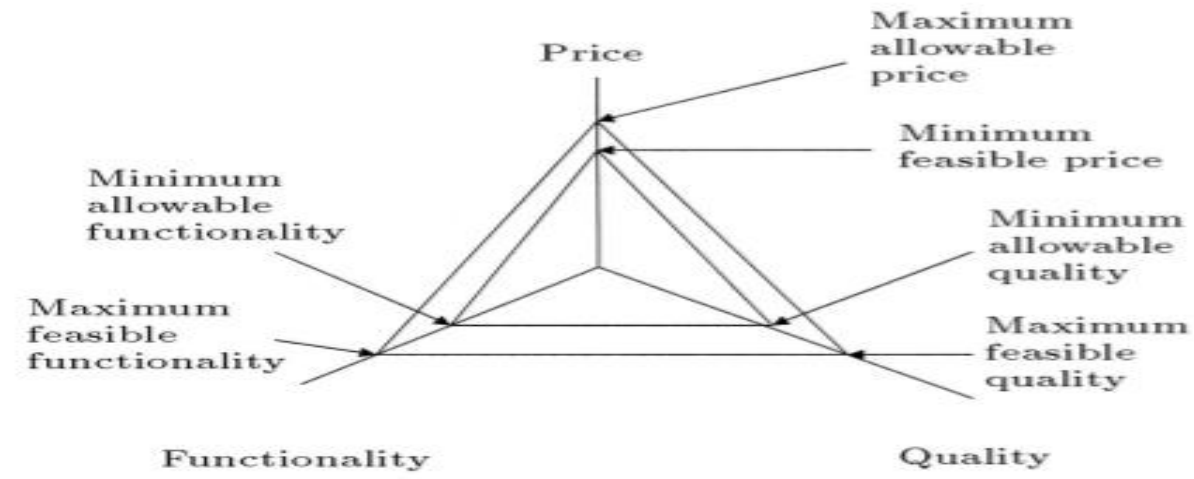

Figure 2 (It shows the factors of product survival: price, quality, and functionality)

Source: (Cooper and Slagmulder, 1997)

It is noted that the effective design of the product requires the existence of functional trust relationships between the various administrative tasks, determining preferences and levels of customer satisfaction can be achieved through an analysis of the quality function deployment, and that determining the level of quality and target costs can be done through the target cost approach, so applying each of the quality function deployment and target cost approach requires a multi-functional team work that includes customers, engineers, designers, accountants and salesmen, and this team helps to correct the quality and functionality of products with the proper pricing of those products (Singh and Kumar, 2014)

If the quality function deployment focuses on the needs of customers at the product design stage, the target cost approach focuses on customer desires, product quality and job performance, without increasing their production costs, and the quality function deployment is integrated with the targeted cost approach to help in managing the cost of products, while enhancing quality specifications, by satisfying customer needs and helping to eliminate functions that do not add value to products (Hertenstein and Platt, 1999).

The following figure 3 shows how to integrate between the QFD and target costing and value engineering to achieve the targeted rationalization. 


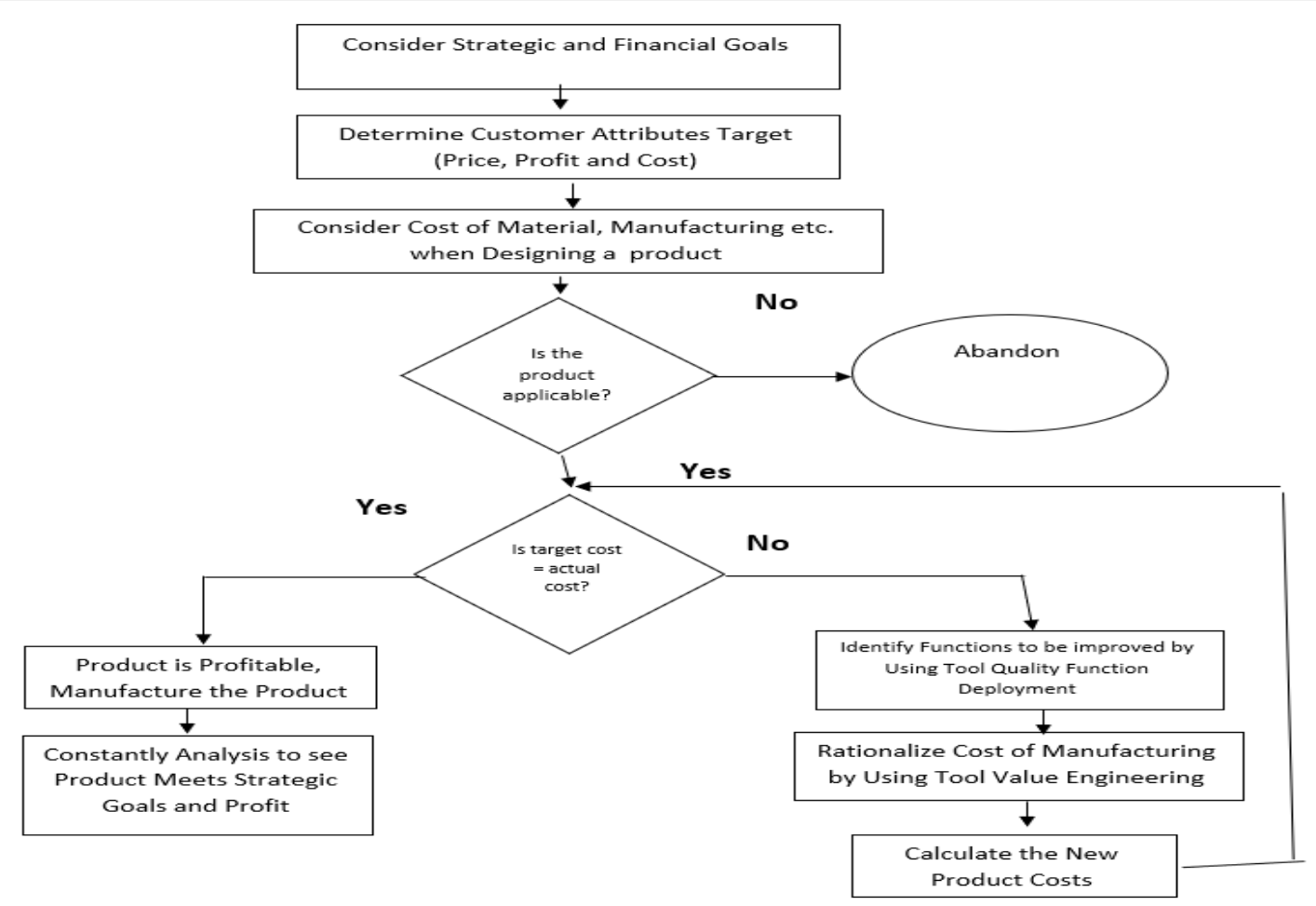

Figure 3 (Integration between Quality function deployment (QFD), Target Costing (TC) and value Engineering (VE) to cost rationalization)

Source: (Amara, 1998)

From the previous figure, it is clear that to achieve the target costing, there must be techniques that help in achieving them, therefore, after the target cost per unit has been determined, it is compared to the initial cost, if the target cost is greater than or equal to the initial cost, then the product is produced, but if the target cost is smaller than Initial cost, then QFD tool is applied. As QFD is considered a support tool for the target costing and value engineering because it helps to design the product by clarifying the correlation between the product components and customer requirements and then reaching the relative importance of each component, then comes the role of value engineering in identifying the candidate components for rationalize and rationalization of their costs without compromising the quality of the product.

Finally, through the previous presentation, it was thought that the use of modern approaches to cost management and rationalization (the target 
cost approach), in addition to auxiliary and supportive tools, works to rationalize the cost to the lowest possible level, in particular the value engineering technique and the quality function deployment, in a way that supports the process of rationalizing costs and controlling them, to reach not only to bridge the cost gap between the actual cost and the target cost, but to reduce the cost over the competitors 'cost to achieve the competitive cost that supports the competitive strategy and improve the overall performance of the facility.

\section{Summary, Results and Recommendations: -}

\section{Summary and Results: -}

The main goal of any organization has become not only to attract customers, but to work to retain them and ensure their loyalty by meeting their various needs and requirements at the lowest possible cost that enables organizations to compete and remain in the market, and considering the importance of each of the goal of providing a high-quality product that fulfills the requirements and specifications desired by the customers at the lowest possible cost, i.e. rationalizing the costs of the products while maintaining the required quality level, and where there is no approach that can be used alone to achieve those goals, it became necessary to integrate two or more approaches to achieve this.

The target costing approach uses the latest management and production techniques, such as the quality function deployment approach and value engineering, in cost rationalization and product development, value engineering with the support of the quality function deployment is considered one of the most important tools and techniques that are used to achieve the target cost by modifying product design and creating new product designs that lead to rationalization of product costs without compromising its quality from the customer's point of view.

The use of target costing approach, value engineering and the quality function deployment as an integrated framework contributes to rationalizing product costs while not compromising their quality, maximizing profitability and improving quality because of their clear role in cost rationalization, as the target costing and value engineering approaches are the most appropriate formula for cost rationalization and 
product pricing as well as Increasing the ability of economic units to compete.

Value engineering is one of the most appropriate methods to integrate with the quality function deployment in order to achieve the target cost, for several reasons, the most important of which are:

-Both value engineering and the quality function deployment agree in the timing of their use, which is the design stage.

-The value engineering aims to rationalize the cost of the product without compromising the desires of the customers, while the quality function deployment seeks to create value for customers without increasing costs, which requires integration to achieve the best possible benefit.

\section{Recommendations: -}

By the end of the current work, we recommend the following:

1-Searching for other approaches and methods to achieve the two goals of improving quality and rationalizing cost, such as Six Sigma methods, and conducting a study linking the quality function deployment with Six Sigma. 2-Examine the extent of integration between the target costing approach and the triz approach in improving product value.

\section{References: -}

\section{$\underline{\text { A. Books }}$}

1. Blocher, E., \& Stout D., \& Cokins, G., (2010):"Cost Management: A Strategic Emphasis", (New York: McGraw-Hill/Irwin, Fifth Edition).

2. Blocher, E., \& Stout, D., \& Juras, P., \& Cokins, G., (2016): "Cost Management-A Strategic Emphasis", McGraw-Hill/Irwin.

3. Cooper, R. and Slagmulder, R. (1997):"Target Costing and Value Engineering", first edition, Productivity Press, New York, NY.

4. El-Helbawy, Saeed Mahmoud \& El-Nashar, Tahani Mahmoud, (2013): "Advanced Management Accounting: Cost Management Approach", Fourth edition, Faculty of Commerce - Tanta University. 
5. Hussein, Ahmed, (2003):"Advanced Management Accounting", Alexandria University, Accounting Department.

6. Langfield-Smith Kim \& Thorne Helen \&Hilton Ronald, (2009): "Management Accounting: Information for creating and managing value", $5^{\text {th }}$ Ed., McGraw-Hill Co.USA.

7. Monden, Y. (1992): "Cost Management in the New Manufacturing Age", Productivity Press, New York, NY.

\section{B. Periodicals}

1. Abdel- Mawgod, Mahmoud Ibrahim, (2017):" A proposed model for a cost reduction strategy in light of the integration between value engineering and value analysis: the case of the Kingdom of Saudi Arabia", Journal of Contemporary Business Research, Sohag University, College of Commerce, Volume 31, Issue 3, pages 193241.

2. Ahmed, abeer thabet, (2018): "A suggested model for the integration between the quality function deployment and value engineering and its impact in providing a high-quality product at the lowest possible cost: A field Study ", Journal of Accounting Thought, Ain Shams University, Faculty of Commerce, Accounting and Auditing Department, Volume 22, Issue 3, pages 400 -440.

3. Ahmed, Marwa Abdullah, (2018):"The effect of integration between the two methods of target cost and value engineering on the competitiveness of the facility", Scientific Journal of Commercial and Environmental Studies, Suez Canal University, Faculty of Commerce, Volume 9, Issue 2, pages 525-553.

4. Al-olimat maha Farhan, (2020):" The role of target cost and value reengineering in reducing production costs in the Jordanian pharmaceutical companies listed on the Amman Stock Exchange", Master thesis, Al-Bayt University, Faculty of Economics and Administrative Sciences, Jordan.

5. AL-Qady mostafa ahmed, (2013):" Improving the cost planning process:RCA approach A case study,master thesis , Tanta University, Faculty of Commerce, Accounting Department.

6. Al-Tammy Khaled Ghazi \& Shihab Rabab Adnan, (2010):"Using Quality Function Deployment (QFD) and Support tools in service 
cost reduction - case Study in hospitals in Aleppo and Mousl", Research presented to the twelfth symposium on ways to develop accounting in the Kingdom of Saudi Arabia entitled: "The accounting profession in the Kingdom of Saudi Arabia and the challenges of the twenty-first century",pages 1:33,http://www.khantakji.com/files/Accountancy/E2 24.pdf.

7. Amara, V. (1998):" Target costing for product design" Virginia: Institute Blacksburg, Virginia.

8. Annappa, C. M. \& Panditrao, K. S. (2013): "Integration of Quality Function Deployment and Value Engineering in Furniture Manufacturing Industry for Improvement of Computer Work Station", International Journal of Innovative Technology and Exploring Engineering (IJITEE), Volume 2, Issue 6, pages 45-52.

9. Chin K. S.\& Yang Q.\& Chan C. Y.\& Tsui K. L.\& Li Y. L., (2019):" Identifying passengers' needs in cabin interiors of high-speed rails in China using quality function deployment for improving passenger satisfaction", Transportation Research Part A, volume 119, pages 326-342.

10.Cooper, R., \& Slagmulder, R., (2004):"Achieving Full- cycle cost management ", MIT Sloan management Review, volume 46, issue 1 , pages $45-53$.

11.El- Dalahmeh, Suleiman Mustafa, (2018):"Extent of Implementing Target Costing and Value Engineering Approach to Reducing Costs: A Survey in Jordanian Shareholding Companies for Food Industries", Asian Journal of Finance \& Accounting, Volume 10, issue 1, pages 390-406.

12.El-balkey faeek, (2008):" Focus on the design stage to identify the target cost of production within the allowable costs", Tikrit Journal of Administrative and Economic Sciences, Tikrit University, Faculty of Administration and Economics Volume 4 , Issue 12,pages 159178.

13.Elhag, meskin\& elyas saleh, (2017):" The integration between the two systems of target cost and value engineering as a tool to reduce costs in the economic institution", El-Mishkat Journal of Economics, Development and Law, Institute of Economic Sciences, Management and Business Sciences, volume 2, issue 4, pages 99- 135. 
14.El-Kababjy Magdy Wael, (2014):" The extent of application of target cost and value engineering as an input to reduce costs in the Palestinian public shareholding industrial companies", Journal of Management Sciences Studies, Jordan, Volume 41, Issue 2, pages 170-190.

15.Gandhinathan, R.\& Raviswaran, N. \& Suthakar, M., (2004): "QFDand VE-enabled target costing: a fuzzy approach", International Journal of Quality \& Reliability Management, Volume 21, Issue 9, pages 1003-1011.

16.Hertenstein J., \& Platt M., (1999): "A Cost/Time Trade-off Framework for New Product Development", International Journal of Strategic Cost Management, Volume 2, Issue 2, pages 31-74.

17.Karimi, Zahra \& Jafari, Alireza (2014): "Cost Management through Using Target Costing, Quality Function Deployment and Value Engineering", Research Journal of Environmental and Earth Sciences, Volume 6, issue 4, pages 233-240.

18. Khalil, alaa mostafa, (2012):"Proposed for Implementation of the target Costing method in Middle East Pharmaceutical CompanyGaza Strip (Case Study)", Master thesis, Islamic University-Gaza, Faculty of Commerce, Accounting and Finance Department.

19.Mahajan Pratik, \& Chamarthi Manohar, \& Bangar, Vaibhav, \& Patel Shital, (2019): "A case study analysis through the implementation of value engineering.", International Research Journal of Engineering and Technology (IRJET), Volume 6, Issue 4, pages 2472 -2477.

20.Prasad, K. \& Subbaiah,K. \&Rao, K.,(2011):"Cost engineering with QFD: Amathimatial model", International Journal for Quality research, volume 5, issue1, pages 33-37.

21.Sharma J. (2012): "A cross disciplinary approach to product development and design through quality function deployment, target costing and value engineering", international journal of productivity and quality management, Volume 9 , issue 3 , pages 309-331.

22.Sharma, A. \& Srivastava, H.\& Belokar, R., (2011):"A Case study analysis through the implementation of value engineering ", international journal of engineering science and technology (IJEST), volume 3, Issue 3, pages 2204-2213.

23.Singh, Shailender \& Kumar, Manish, (2014): "Integration of Quality Function Deployment and Target Costing", International Journal of 
Computer Applications, National Conference on Advances in Technology \& Applied Sciences (NCATAS), pages 16-19.

24.Vijayan R.\& Geetha T. \&Nishanth B.\& Tamilarasan M.\& Kumar V., (2019):" Value engineering and value analysis of rear air spring bracket, Materials Today", Proceedings, Volume 16, Pages 10751082.

25.Yegenegi, K.\& Arasti, M.\& Mousakhani, M., (2011):" The integration of QFD technique and value engineering and its applying in healthcare center", International Conference on Industrial Engineering and Operations Management Kuala Lumpur, Malaysia,Pages 650-659. 